\title{
REVIEW ASSESSMENT OF BIODIVERSITY LOSS OF SUNDARBAN FOREST: HIGHLIGHTS ON CAUSES AND IMPACTS
}

\author{
Md. Shohel Khan ${ }^{1 *}$, Shahriar Abdullah ${ }^{1}$ Mohammed Abdus Salam ${ }^{1}$ Tanwee Rani Mandal ${ }^{2}$, \\ and Md. Rajib Hossain ${ }^{3}$ \\ ${ }^{1}$ Department of Environmental Science and Disaster Management, Noakhali Science and Technology \\ University, Noakhali-3814, Bangladesh \\ ${ }^{2}$ Department of Geography and Environment, Govt. Sundarban Adarsha College, \\ Khulna, Ministry of Education, Bangladesh \\ ${ }^{3}$ Department of Environmental Science and Disaster Management, Bangabandhu Sheikh Mujibur \\ Rahman Science and Technology University, Gopalganj-8100, Bangladesha
}

Received: 22 August 2019, Revised: 21 April 2021, Accepted: 22 April 2021

REVIEW ASSESSMENT OF BIODIVERSITY LOSS OF SUNDARBAN FOREST: HIGHLIGHTS ON CAUSES AND IMPACTS. Sundarban, the world biggest mangrove forest, was announced as a World Heritage in 1997 and Ramsar Site in 2007. Its 62\% lies in Bangladesh (Khulna, Bagerhat, Satkhira, Pirojpur, and Barguna Regions) and 38\% in India, that become a vanguard for coastal communities. This ecosystem's floral and faunal structure incorporates 334 floral, 300 birds, 120 fish, 35 reptiles, and 32 mammals species. It contributes $41 \%$ of the total forest income of Bangladesh. This paper is intended to recognize the significant reasons for biodiversity calamity and its related effects on lives and degradation of the environment. A total of 105 published articles and reports were identified by searching four keywords: degradation, biodiversity, Sundarban, and Bangladesh. By considering the scope, 28 articles and 17 reports were incorporated to satisfy the objectives. The study revealed that the prominent causes of biodiversity loss of Sundarban might be due to intensified shrimp cultivation, increased dependency on forest and illicit felling, changing land use pattern, oil spillage, and pollution, forest fire, improper management practices, plant diseases, tourism activities, upstream withdrawal of river water, salinity intrusion, climate change, and some natural causes. The impacts were the loss of diversity of floral and faunal species subjected to regionally extinct, critically endangered, endangered, vulnerable, near threatened, and least concern condition. Occupational change and deterioration of the quality of life of surrounding communities are identified as impacts. Finally, the study recommended the formulation of a special mangrove forest policy and proper management practices of Sundarban with several environmental protection strategies that should be adopted to conserve this unique ecosystem.

Keywords: Mangrove forest, environmental instability, environmental protection, shrimp farming

TINJAUAN PENIL ALAN HILANGNYA KE ANEKARAGAMAN HAYATI HUTAN SUNDARBAN: PENYEBAB DAN DAMPAK. Sundarban merupakan butan bakau terbesar di dunia dan telah diumumkan sebagai Warisan Dunia pada tabun 1997 dan Situs Ramsar pada tabun 2007. Sebanyak. 62\% terletak. di Bangladesh (Wilayab Khulna, Bagerhat, Satkbira, Pirojpur, dan Barguna) dan 38\% di India, yanag menjadi perintis bagi masyarakat pesisir. Struktur flora dan fauna ekosistem ini mencakup 334 flora, 300 burung, 120 ikan, 35 reptil, dan 32 spesies mamalia. Sundarban menyumbang 41\% dari total pendapatan butan Bangladesh. Tulisan ini bertujuan mempelajari dampay nyata berkurangnya keanekaragaman hayati dan pengarubnya pada kehidupan dan degradasi lingkungan. Sebanyak. 105 artikel dan laporan yang diterbitkan diidentifikasi berdasarkan empat kata kunci: degradasi, keanekaragaman bayati, Sundarban, dan Bangladesh. Dengan mempertimbangkan ruang lingkupnya, 28 artikel dan 17 laporan dimasukean untuk memenubi tujuan. Hasilpenelitian mengungkapkan bahwa penyebab utama bilangnya keanekaragaman hayati di Sundarban disebabkan oleh peningkatan budidaya udang, peningkatan ketergantungan pada butan dan penebangan liar, perubahan pola penggunaan lahan, tumpahan minyak dan polusi, kebakaran butan, praktik pengelolaan yang tidak tepat, penyakit tanaman, kegiatan pariwisata, pengambilan air sungai di bulu, intrusi salinitas, perubahan iklim, dan beberapa penyebab alami. Dampaknya adalah hilangnya keanekaragaman jenis flora dan fauna yang terancam punah secara regional, terancam punah, hampir

*Corresponding author: sajibicb@gmail.com 
punah, rentan, terancam, dan kondisi paling tidak mengkhawatirkan. Perubahan pekerjaan dan penurunan kualitas hidup masyarakat sekitar diidentifikasi sebagai dampak. Hasil, studi merekomendasikan perumusan kebijakan khusus butan bakau dan praktik pengelolaan Sundarban yang tepat dengan beberapa strategi perlindungan lingkungan yang harus diadopsi untuk. melestarikan ekosistem yang unik ini.

Kata kunci: Hutan Bakau, instabilitas lingkungan, perlindungan lingkungan, tambak udang

\section{INTRODUCTION}

Bangladesh covers a total of 14.75 million ha (Hossain, Ahmed, Azad, \& Hasan, 2020), of which approximately 13.5 million ha are land surfaces and 0.94 million ha are rivers and various inland water bodies (Islam, 2005). Sundarban is the largest and oldest systematically managed mangrove forest (Chakravortty \& Ghosh, 2018) that stretches over Bangladesh and India. It covers the vicinity of 0.6 million ha $(4.07 \%$ of the total area of Bangladesh) represents a unique ecosystem. It is the most economically precious and the richest natural forest in Bangladesh. Sundarban constitutes around $51 \%$ of the total reserved forest and contributes around 41\% of the forest income. In 1997, the area was declared as World Heritage Site by UNESCO, and in 2007 the Sundarban was perceived as a Ramsar Wetland Site by Ramsar Convention. Around one million individuals procure their business from the forest (Khulna University, 2001; Islam \& Bhuiyan, 2018).

The forest secures land on the coast against interruption by saltiness from the ocean (Iftekhar \& Islam, 2004). Evidence advocate that the ecosystem is under stress and showing signs of depletion. The anthropogenic impact on mangroves has quickened unexpectedly over the last decades. Mangroves are feeling the squeeze by numerous dangers, for example, human infringement, shrimp cultivation and different kinds of aquaculture, farming, diseases, catastrophic events and regular changes in hydrology, ocean level ascent, and inadequate recovery. Furthermore, there have been impacts of mis-management and corruption because of the improvement of the two most basic ocean ports at Mongla and Chattagram (Rahman, Mohammed, Rahman, \& Islam, 2010). This paper studies the factor that causes biodiversity loss of the Sundarban, weakening of mangrove timberland, and evaluates the impacts on species and lives.

\section{MATERIAL AND METHOD}

\section{A. Method}

The systematic assessment coordinated evaluation of the biodiversity loss and debasement of the world biggest mangrove forest, the Sundarban in Bangladesh. The articles and reports had been identified through online search from different search engine. "Degradation", "Biodiversity", "Sundarban", and "Bangladesh" were used as keywords to find journal articles and reports. A total of 105 papers were found, but after removing duplications and irreverent articles and reports, 28 journal articles and 17 reports were incorporated for this study (Figure 1). Some secondary data were added from Bangladesh Bureau of Statistics (BBS), Food and Agriculture Organization (FAO), United Nations Environment Program (UNEP), United Nations Framework Convention on Climate Change (UNFCCC), Intergovernmental Panel on Climate Change (IPCC) and Non-governmental Organization (NGO) publications

\section{B. Study Site}

The Sundarban is shaped with several islands from freshwater commanded streams by utilizing the sediment deposition by the Ganga, Brahmaputra, and Meghna (GBM) river systems. The total area of this forest is 1,000,000 ha, of which $62 \%$ is in Bangladesh, lies between $89^{\circ} 00^{\prime}-89^{\circ} 55^{\prime} \mathrm{E}$ longitude and $21^{\circ} 30^{\prime}-22^{\circ} 30^{\prime} \mathrm{N}$ latitude (Figure 2), and 38\% lies in India. The total Sundarban area of Bangladesh is 599.330 


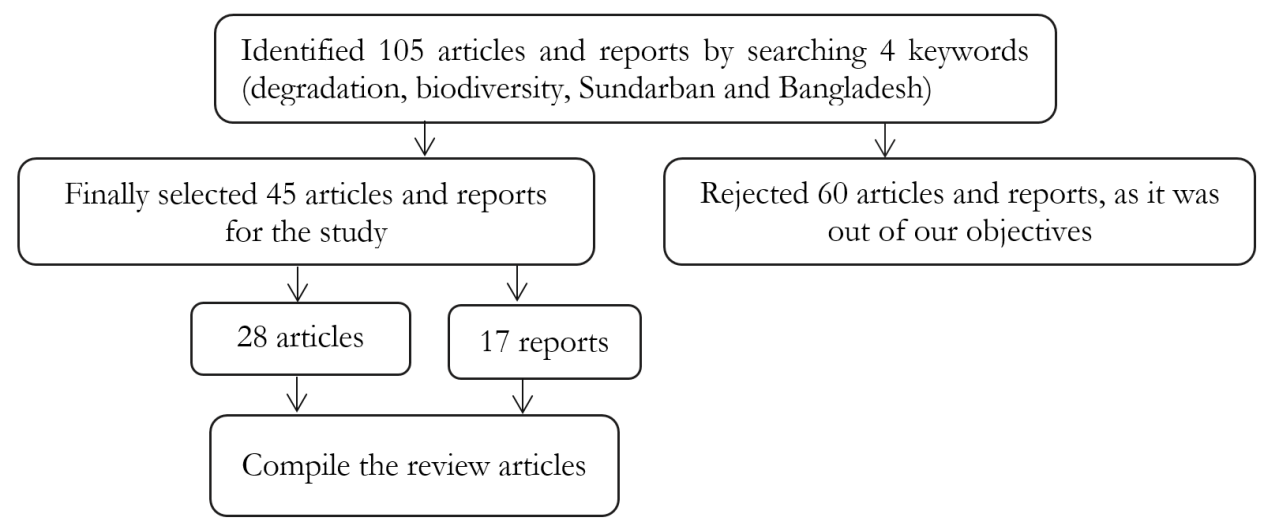

Figure 1. Review processes for this study

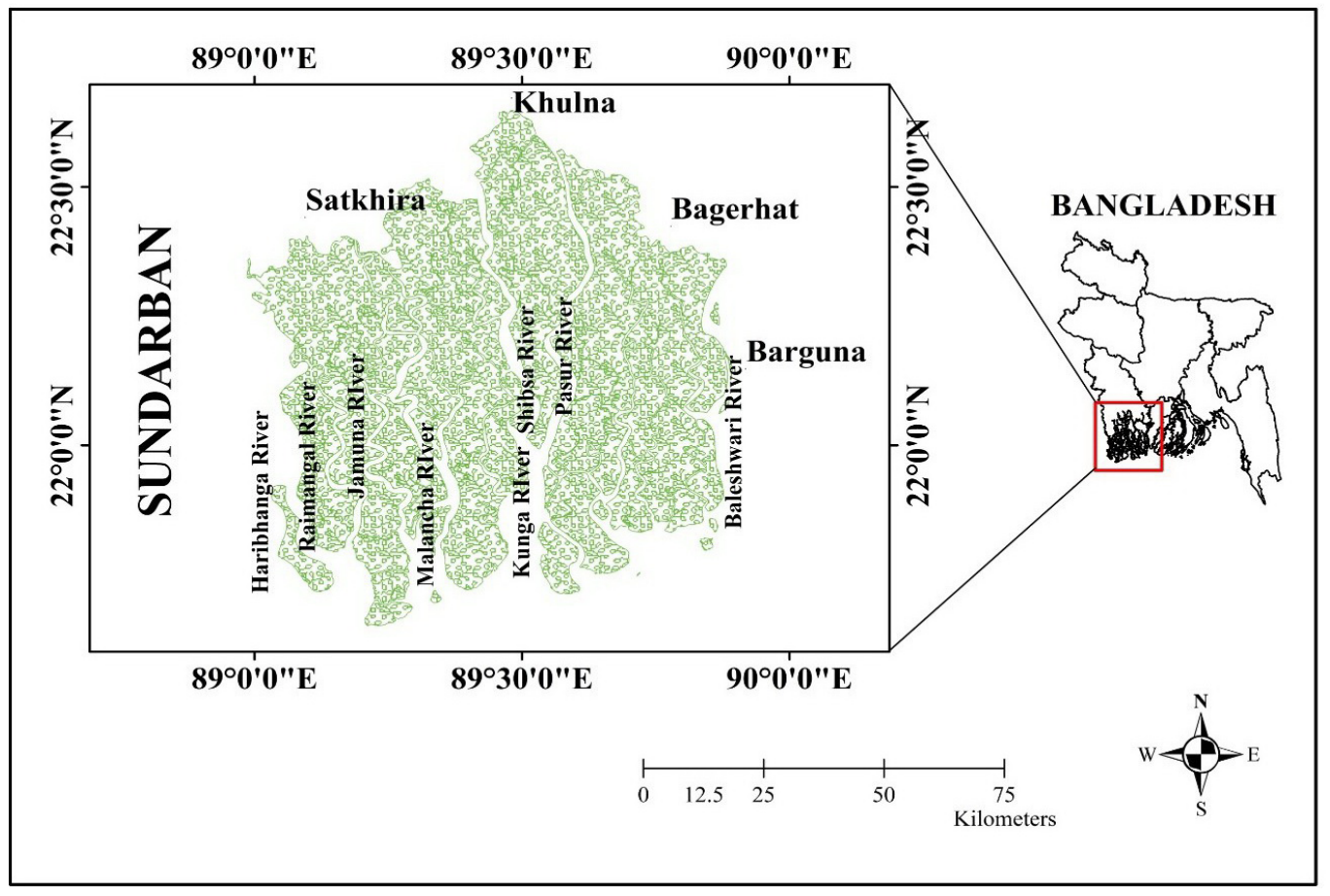

Figure 2. Map of the study area

ha consists of about 400 tidal rivers, canals and 200 islands (Banglapedia, 2010; Islam \& Bhuiyan, 2018). The maximum elevation of the Sundarban is $10 \mathrm{~m}$ above sea level, and it has high clay, soil.

The saltiness of Sundarban increases from north to south and east to west, and the vegetation diminishes from these bearings. It was proclaimed as Reserve Forest in 1875-76 and placed under Forest Department (FD) for management (Rahman, 2000). The place's climate is characterized by relatively excessive temperature and humidity at some point of the year and well-dispensed rainfall during the monsoon season. Temperature varies from a minimum of 2 to $4^{\circ} \mathrm{C}$ to a maximum of 32 to $43^{\circ} \mathrm{C}$ (Agrawala, Ota, Ahmed, Smith, \& van Alst, 2003; Gopal \& Chauhan, 2006). The Sundarban mangrove forest represents around $50 \%$ of the country's protected area, and around 2 million people are directly or indirectly relying upon its resources. 


\section{RESULT AND DISCUSSION}

\section{A. Causes of Degradation of Sundarban Mangrove Ecosystem}

The forest is the most complex environment on the planet (Rahman, Mahabubur, Chongling, Islam, \& Haoliang, 2009). Over the top, asset extraction and ignoring replanting were the key reasons for the reduced supply of consumer goods for the development of Sundarban forest (Ali, Kabir, \& Hoque, 2006). The total area of the Sundarban forest has been reduced from 20.3 to 10.9 million ha from 1959 to 1996 (FAO, 2000). The reasons for the crumbling of the Sundarban mangrove forest biological system is depicted below.

\section{Increased Shrimp Farming Practices}

The swiftly increasing shrimp farming enterprise possesses the impact on deteriorating the mangrove forests in Bangladesh. Moreover, mangroves have been used for fishing, shrimp farming, crabs farming, and mainly huge Penaeus monodo (tiger prawn) farming (Islam \& Bhuiyan, 2018). The entire vicinity under brackish water shrimp farming was increased from 51,812 to $2,17,000$ ha in $1984-2008$ in the coastal areas of Bangladesh (Miah et al., 2010). During shrimp cultivation, individuals utilized urea, which mixed with salty water, resulted in the degradation of the aquaculture lakes of Bangladesh that preserving the wastewater of Sundarban.

\section{Increased Over-dependency of the Population and Illegal Forest Cutting}

The increased population has been recognized as extra stress on the Sundarban mangrove forest environment, and it accelerates the degradation of forest resources and their production. Over-extraction of forest resources to meet the demand of growing requirements of humans being another important factor for decreasing the Sundarban. It has been overexploited for timber, fuelwood, bark tannin, animal fodder, native medicines, and food (fish, shellfish, honey and wild animals) for decades to centuries.

\section{Oil Spillage and Pollution}

Oil spillage is an extreme risk for damaging aquatic species and unfavourable for sea birds in the mangrove forest region. Contamination arises from oil tanker cargo accidents because Mongla Seaport is situated just $3 \mathrm{~km}$ away from the Sundarban, and about 1,500-1,600 vessels and 12,000-13,000 cargo ships (Rahman et al., 2009) used the internal river routes of this forest. In 2014, an oil tanker carrying 358,000 litres of furnace oil collided with a cargo vessel and sank in the Shalla river, resulting in that oil spread over 2,000 ha of the Sundarban (The Daily Star, 2014). Bangladesh imported approximately 1.2 and 0.5 million heaps of crude oil and refined oil annually, which is frequently shipped by small tankers (Islam \& Bhuiyan, 2018). Contamination occurred from these vessels from unintentional spillage. The oil connected to the leaf can block up stomata and have a negative impact on photosynthesis, respiration, and water metabolism of the mangrove plant life cycle (Peng \& Qin, 2000). Mechanical improvement, industrial farming practice and aquaculture near the Sundarban stream bowls, expanded populace attempted to modernize privates in coastal zones, had prompted extensive amounts of waste, squander water and poisons released to the mangrove wetland (Rahman et al., 2009).

\section{Fire}

Fire can likewise have achieved probably the most genuine harm to the mangrove environment in recent years. On March 20, 2010 , around 250 ha habitat of plants and wild lives had been wrecked through fire. In 2007-2010, 12 incidents of fires happened in the Sundarban (MoEF, 2010). The Sundarban occupies a few shrubs that produce abundant nectar and pollen, and these shrubs are utilized by honey bees (Rahman et al., 2010). To collect honey from the nest, individuals set up a fire to displace the bees, and as a result, this could create a forest fire. 


\section{Management Failure}

Area of forest, diversified species and ecosystem characteristics has decreased, even though different forest policies, legal frameworks and plans have been enacted to guard them. The effectiveness of these policies and plans is restrained with the aid of a negative implementation ability (Iftekhar \& Islam, 2004). The lack of professionals, skilled officers; failure of institutions to effectively manipulate coastal mangrove sources; conflicting activities, negative planning, and aptitude of coastal land use; the non-execution of progress plan was the real reasons mangrove forest administration's disappointment. However, negligence and corruption amongst the personnel of authorities and forest department alongside the collaboration of neighbourhood's political leaders with the encroachers add to the administration's failure (Akhtaruzzaman, 2004; Rahman et al., 2010). However, governmental bodies tried to undertake pure conservation planning initiatives from 1960 to 2001. Although, Environmental policy, national conservation strategy and national environmental management active plan are aiming to protect mangrove ecosystems, but management strategies based totally on logical and scientific establishment have not been created until today (Islam \& Wahab, 2005). At last, the national forest policy 2016 was finally prepared to protect the forest of Bangladesh.

\section{Plant Diseases}

Top dying, a dominant disease of Heritiera fomes, is one of the major causes of the deterioration of the forest. More than $5-6 \%$ of the entire Heritiera fomes are now suffering from top dying, and half of them have already been affected due to salinity intrusion. Islam and Wahab (2005) showed that about $70 \%$ of Heritiera fomes stems were severely affected by top dying diseases.

\section{Upstream Withdrawal of River Water and Salinity Intrusion}

Sundarban mangrove forest acquires freshwater discharge typically from the flow of the Ganges River (Rahman et al., 2017). Stream of Ganges, Brahmaputra, and Meghna rivers were the primary wellsprings of freshwater in Bangladesh (Rahman, Islam, \& Rume, 2016). India built the Farakka barrage upstream of the Ganges River in 1974. The unilateral withdrawal of water from the Ganges induced a large discount in the discharge of Ganges through Bangladesh. The average month-tomonth water going through dry season used to be 2,674 cubic meters per second (cumecs) from 1935-1975, which went down to 1,871 cumecs from 1975-2004, showing about a 30\% decrease at some phase in the post-dam period. After 1975, the pattern was modified due to the diversion of water at Farakka Barrage in India, simply $17 \mathrm{~km}$ upstream from Bangladesh (Mirza, Warrick, Ericksen, \& Kenny, 1998). As a result of the regeneration of Heritiria fomes, the dominant timber species of Sundarban has decreased in the southwestern region (Paul, Ray, Kamila, \& Jana, 2017). It affects the excessive salinity affected area (Table 1$)$. The percentage of salinity stress concerning the number of days is in (Islam \& Gnauck, 2011) and incorporated in Table 2.

\section{Natural Causes}

Various natural calamities like cyclone, flood, storm surges, coastal bank erosion, naturally

Table 1. Salinity rate of various areas of Sundarban

\begin{tabular}{ccc}
\hline Coverage area (ha) & Coverage area $\mathbf{( \% )}$ & Salinity $\left(\mathbf{d S} / \mathbf{m}^{*}\right)$ \\
\hline 4813.60 & 80 & $>2415$ \\
421.19 & 7 & $21610-32415$ \\
421.19 & 7 & $10805-21610$ \\
361.02 & 6 & $<10805$ \\
\hline
\end{tabular}

Remarks: *dS/m represents decisiemens per meter, Source: Islam and Gnauck (2011) 
Table 2. Salinity stress during 2001-2002 inside the Sundarban

\begin{tabular}{|c|c|c|c|c|c|c|c|}
\hline \multicolumn{8}{|c|}{ Percentage of area $(\%)$ under different salinity $(\mathrm{dS} / \mathrm{m})$ level } \\
\hline $\begin{array}{l}\text { Duration } \\
\text { (days) }\end{array}$ & $\begin{array}{l}>54,025 \\
(\mathrm{dS} / \mathrm{m})\end{array}$ & $\begin{array}{c}43,220-54,025 \\
\text { (dS/m) }\end{array}$ & $\begin{array}{c}32,415-43,220 \\
(\mathrm{dS} / \mathrm{m})\end{array}$ & $\begin{array}{c}21,610-32,415 \\
(\mathrm{dS} / \mathrm{m})\end{array}$ & $\begin{array}{c}10,805-21,610 \\
(\mathrm{dS} / \mathrm{m})\end{array}$ & $\begin{array}{l}<10,805 \\
(\mathrm{dS} / \mathrm{m})\end{array}$ & $\begin{array}{c}\text { Area } \\
\text { (percent) }\end{array}$ \\
\hline 120 & 0 & 25 & 28 & 19 & 15 & 13 & 100 \\
\hline 90 & 6 & 31 & 28 & 15 & 14 & 6 & 100 \\
\hline 60 & 6 & 31 & 28 & 15 & 15 & 5 & 100 \\
\hline 45 & 28 & 30 & 17 & 11 & 10 & 4 & 100 \\
\hline 30 & 29 & 30 & 17 & 11 & 9 & 4 & 100 \\
\hline 15 & 29 & 30 & 17 & 11 & 9 & 4 & 100 \\
\hline
\end{tabular}

Source: Islam \& Gnauck (2011)

shifting hydrology, and climate change would destroy trees and animals faster. The damage to Sundarban precipitated through the latest cyclone Sidr (hit on 15 November 2007) has been preliminarily assessed at $\$ 142.9$ million (Saadi, 2010). A document by UNESCO, entitled Case Studies on Climate Change and World Heritage, has referred to that as an anthropogenic $45 \mathrm{~cm}$ ascent of sea-level liable to occur with the asset of the quilt of the $21^{\text {st }}$ century. Following IPCC, mixed with different sorts of anthropogenic stress on the Sundarban might also want to lead to the destruction of $75 \%$ of the forest (UNESCO, 2007). Rising seas are stated to have flooded 7,500 ha of mangroves in the Sundarban (WWF, 2007).

\section{B. Impacts on Mangrove Forest}

\section{Biodiversity Loss of Sundarban Mangrove Forest}

The Sundarban, the biggest chunk of swamp mangrove forest, was underneath the ocean around 4,000 years ago (Ali, 1994). Pedologically, the forest's soil is young, inadequately depleted with uncured deposits having no distinct horizon. It bolsters above 245 to 300 genera species of flora, above 120 species of fish, 35 species of reptile, more than 300 species of birds, and 32 species of mammals (IUCN, 2001). Chaffey et al. (1985) recorded around 334 plant species, which comprises 35 vegetables, 29 types of grass, 19 sedges, 18 euphorbia, and 50 mangrove plant species (Table 3). It has mentioned that mangrove forests were the territories of 500 species of wild vascular plants. In understanding FAO gauges, the Sundarban mangrove forest is home to around 840 species of wild creatures, including Royal Bengal tigers. More than 120 species were noted to be caught by fishermen (Rahman et al., 2010).

Sundarban has an extraordinarily rich diversity of aquatic and terrestrial flora and fauna. But the quantity is reducing continuously. The preoccupation of the normal courses of waterways, development of banks, dams; extensions in the upstream; diminished buoy of freshwater in the streams brought about the expansion in the degree of saltiness; oversalting in numerous spots caused consequent adjustments in the mangrove biological community (Rahman, 2015). Both natural and anthropogenic causes are responsible for the biodiversity loss of Sundarban. Several species have been regionally extinct from Sundarban, and many more are critically endangered, endangered, vulnerable, near threatened, and least concern species from Sundarban. The details are shown in Table 4.

\section{Economical Loss}

Economically, Sundarban produces raw materials for privates (fuelwood, furniture, house construction, charcoal, match sticks, and newsprints) and public goods (air, natural beauty, fisheries, and navigation). Up until this point, distinctive techniques have been created for the better utilization of private 
Table 3. The wildlife species of Bangladesh Sundarban

\begin{tabular}{lrrr}
\hline \multicolumn{1}{c}{ Fauna species } & Number umber & Flora species & Number \\
\hline Fish & $177^{2}, / 120^{7}$ & Plants & $334 / 300^{8,9}$ \\
Amphibians & $8^{4,6} / 11^{2}$ & Mangrove & $50^{8,9}$ \\
Reptiles & $50^{4} / 53^{1} / 35^{7}$ & Legumes & $35^{8,9}$ \\
Birds & $261^{5} / 320^{1} / 300^{6,7}$ & Grasses & $29^{8,9}$ \\
Mammals & $50^{5,6} / 32^{7}$ & Sedges & $19^{8,9}$ \\
Shrimp & $24^{6}, 24^{3}$ & Euphorbias & $18^{8,9}$ \\
Crabs & $7^{6,3}$ & Flowering Plants & $105^{8,9}$ \\
Mollusca & $8^{1}$ & Algae & $150^{8,9}$ \\
Lobster & $8^{1}$ & Lichens & $32^{1}$ \\
Cetaceans & $11^{12}$ & Shrubs & $25^{11}$ \\
Invertebrates & $873^{2}$ & Herb & $10^{11}$ \\
Waterfowl & $95^{10}$ & & \\
Raptors & $38^{10}$ & & \\
Kingfisher & $9^{10}$ & & \\
Insects & $2,493^{10}$ & & \\
Mites & $19^{10}$ & & \\
Echinoderms & $4^{10}$ & & \\
Aquatic species & $678^{12}$ & & \\
\hline
\end{tabular}

Sources: ${ }^{1}$ Gopal \& Chauhan (2006), ${ }^{2}$ S. Rahman (2012), ${ }^{3}$ IUCN (2003), ${ }^{4}$ Khan (1986), ${ }^{5}$ Khan et al. (2013), ${ }^{6}$ MoEF (2005), ${ }^{7}$ IUCN (2001), ${ }^{8}$ Chaffey (1985), ${ }^{9}$ Naskar \& Mandal (1999), ${ }^{10}$ Rahman (2015), ${ }^{11}$ Aziz \& Paul (2015), ${ }^{12} \mathrm{MoEF}$ (2010)

Table 4. IUCN status of different species in Sundarban

\begin{tabular}{lllllc}
\hline \multicolumn{1}{c}{ Scientific Name } & \multicolumn{1}{c}{ Local name } & Status $^{*}$ & Scientific name & Local name & Status* $^{*}$ \\
\hline Bubalus bubalis & Wild buffalo & EN & Semnopithecus pileatus & Capped Langur & NT \\
Cervus duvauceli & Swamp Deer & VU & Lutrogale perspicillata & Smooth-Coated Otter & VU \\
Rhinoceros sondaicus & Javan Rhinoceros & CR & Aonyx cinerea & Oriental Small-clawed Otter & VU \\
Crocodylus palustris & Marsh Crocodile & VU & Viverra zibetha & Great Indian Civet & LC \\
Panthera tigris & Royal Bengal Tiger & NT & Aglaia cucullata & Pacific maple & NT \\
Crocodylus prosus & Estuarine Crocodile & LC & Cynometra ramiflora & Cynometra & LC \\
Lepidochelys olivacea & Olive Ridley Turtle & VU & Eretnochelys imbricate & Hawks Bill Turtle & CR \\
Batagur baska & River Terrapin & EN & Platanista gangetica & Gangetic Dolphin & EN \\
Chelonia mydas & Green turtle & EN & & & \\
\hline
\end{tabular}

Sources: Gopal \& Chauhan (2006), Khan et al. (2013), Aziz \& Paul (2015), IUCN (2000)

*Note: CR, EN, VU, NT and LC represent Critically Endangered, Endangered, Vulnerable, Near Threatened and Least Concern

goods (Timberg, 1991), which more often than not empowers appointment of assets ahead of schedule as could be allowed (Ruitenbeek, 1998) as they depend on the limited future incentives from the present ones. The full value of the public goods supplied by the Sundarban mangrove ecosystem is not recognized, as many of these items and offerings are now not traded in open markets. The Sundarban is losing its aesthetic beauty day by day. If this continues, the tourist will no longer be interested in visiting Sundarban. The traditional use of fuelwood prompts loss of biodiversity, and most of them are financially very important (Islam \& Bhuiyan, 
2018). Recent cyclones Sidr, Reshmi and Aila, affected Sundarban as detailed by numerous authors (Deb \& Ferreira, 2017; Dutta, Das, Paul, Shama, \& Dadhwal, 2015; Islam, 2013; Islam \& Wahab, 2005). Saadi (2010) reported the annual loss of about $\$ 142.9$ million by cyclone Sidr that hit over Sundarban in 2007.

Sundarban is a standout amongst the most various thriving ecosystem communities on the planet (Borrell, Tomero, Bhattacharjee, \& Aguilar, 2016). It went about as a protective obstruction amid the catastrophic time frame for the coastal communities (Bhowmik \& Cabral, 2013; Islam, 2013) and served as various monetary, social and natural advantages. This forest also provides occupation for nearby people through fishing, nectar and wax collection, tourism, wood, and non-wood items (Table 5).

There were $45 \%$ mammals, $42 \%$ birds, $46 \%$ reptiles and 36\% amphibian species found in Sundarban. In the Fiscal year 2003 2004, the evaluated wood production by the forest department was 4,33,000 ton (Uddin, van Steveninck, Stuip, \& Shah, 2013). The income profits from the forest are increasing because the number of tourists and visitors are improved by nearly 25 times in 2012-2013 in contrast to 2000-2001 (Islam \& Bhuiyan, 2018). The provisioning and social administrations gave by the Sundarban added to the income of the Forest Department (FD) US\$ 7,44,000 and US $\$ 42,000$ every year separately amid the financial years from 2001-2002 to 2009-2010 (Uddin et al., 2013). Among all items, income from timber was the most elevated one (US\$ 0.4 million), fish (US\$ 0.2 million), covering materials, fuelwood, crab and nectar and wax (Uddin et al., 2013).

\section{Sea Level Rise}

Sundarban will be submerged due to the rise of sea level. Climate change induces higher evapotranspiration, and low drift in winter would increase salinity. As a result, an increase in fresh water-loving species would be impaired (World Bank, 2000). Habib (2011) affirmed the positive trend of heavy rainfall that is considerable growing during pre-monsoon $(+0.00258 /$ year $)$ and throughout monsoon (+0.0053/year). From 1950 to 1990, excessive cyclones were merely occurring it used to be 7 (Habib, 2011), however during 20 years (19912010) the numbers have increased.

Basak et al. (2013) examined the variation of temperature and precipitation of 34 stations of Bangladesh over the 33 years' time frame (1976 to 2008). They observed that the average maximum temperature has been growing at a change of $0.018 \mathrm{C}^{\circ}$ /year. The sea degree along the Bangladesh coast is rising at about $3 \mathrm{~mm} /$ year, and the seafloor temperature is showing a rising trend (World Bank, 2010). This mangrove forest is the passing route of cyclones formed over the sea or down from the Himalayas. During the last 135 years, about 45 cyclones crossed the coastal belt of Bangladesh, 13 have trekked through the Sundarban (IPAC, 2012). The great impacts would be ocean level ascent, increment in the recurrence and force of the cyclonic tempest, unpredictable precipitation, saltiness interruption, etc. Sundarban will be underwater concerning developing the rise of sea level. Around $15 \%$ of the forest will go

Table 5. Uses of economically important plants of Sundarban

\begin{tabular}{ll}
\hline \multicolumn{1}{c}{ Uses } & \multicolumn{1}{c}{ Species } \\
\hline Fuelwood & Avicennia officinalis, Lumnitzera racemosa, Cynometra ramiflora, Ceriops decandra \\
Furniture, bridges and house & Xylocarpus mekongensis, Xylocarpus granatum, Phoenix paludosa, Bruguiera spp., \\
construction & Sonneratia apetala \\
Charcoal & Cynometra ramiflora, Ceriops decandra \\
Match sticks and newsprint & Excoecaria agallocha \\
\hline
\end{tabular}

Source: Islam \& Bhuiyan (2018), Siddiqi (1998) 
Table 6. Predicted ecosystem loss with sea-level rise in Sundarban

\begin{tabular}{ccc}
\hline Year & Ecosystem loss (\%) & Sea level rise $(\mathbf{c m})$ \\
\hline 2020 & 15 & 10 \\
2050 & 40 & 25 \\
2100 & 100 & 100 \\
\hline
\end{tabular}

Source: Karim (2012)

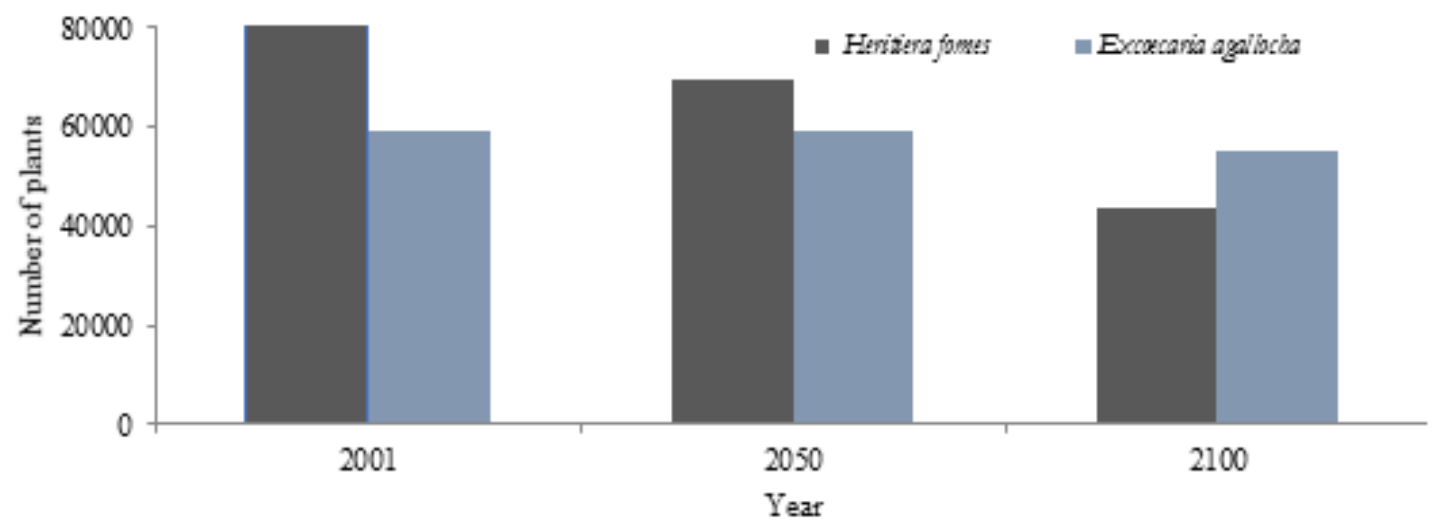

Figure 3. Projected comparison between Heritiera fomes and Excoecaria agallocha in Sundarban Source: CEGIS (2006)

underwater as long as the sea level rises $10 \mathrm{~cm}$ and will be fully destroyed if the sea level rises above $100 \mathrm{~cm}$ (Table 6) (World Bank, 2000).

Due to the impact of climate change, species like Heriteria fomes (Sundari) would be replaced by less valuable species like Ceriops spp. (Goran.) and Excoecaria agallocha (Gewa) (World Bank, 2000). Heriteria fomes and Excoecaria agallocha trees will decrease by $45 \%$ and $7 \%$ respectively by 2100 (Figure 3) from the base year 2001 due to $88 \mathrm{~cm}$ sea-level rise (CEGIS, 2006).

\section{Environmental Instability}

The environmental condition of the Sundarban mangrove forest is getting unstable caused by several elements. Shrimp farming, increased salinity, accidents like oil spill and fire, pollution, climate change, and many others were the foremost reasons. In the south-eastern parts of Bangladesh, 18,200 ha of Chakaria Mangrove Sundarban had nearly been destroyed to make shrimp aquaculture (Akhtaruzzaman, 2004). The government has led different development projects for shrimp aquaculture, founded by the Asian Development Bank and World Bank. Perhaps it would have bought tremendous destruction to the forests (Paul \& Vogl, 2011). It has been determined that, at high salinity, the predominant cause of the decrease in growth is the reduction in the expansion rate of the leaf, which is caused by the high salt concentrations (Zaman, Bhattacharyya, Pramanick, Raha, Chakraborty, \& Mitra, 2014). The relative leaf augmentation and net absorption diminish in mangrove species as salinity increases. Salinity influences the normal development and efficiency of mangroves. This prompts loss of biodiversity and helpful asset of Sundarban, and subsequently, the ecological condition ends up being unpredictable.

\section{More Vulnerability}

The Sundarban is a disaster-prone forest due to common disasters, namely flood, tropical cyclone, tornado, storm surge, salinity and coastal erosion (Shamsuzzoha \& Biswas, 2010). 
The degradation of the forest is accountable for the change in climatic status, and climate change is triggering natural calamities. Extreme activities impact ecological and human systems causing human suffering and monetary losses, thereby impacting human well-being. The Sundarban support a huge population in the surrounding regions, and these are currently benefiting from the coastal protection provided by the mangrove forests (Uddin et al., 2013). The Sundarban works as a barrier for various natural disasters (i.e., cyclone, storm, typhoons, coastal flooding) that first strike on the coastal sector of Bangladesh. The rate of destruction was limited till the last decade. As the safety barrier is damaging day by day, the damages are increasing all over the country.

\section{Ecological Health Risk and Causes and Impacts on Unhealthy Environment}

Oil spillage and water pollution degrade the environment of Sundarban, which creates several ecological health risks. Rapidly increasing variety of marine transports, oil and other chemical substances are mixing with the aquatic system. Consequently, the water is getting polluted, and the diversity of species in both water and land are facing threats. Oil from the fuel tank spread approximately 15 $\mathrm{km}$ downstream from the ship and influenced an impressive segment of the Sundarban mangrove region. It was responsible for the instantaneous mortality of seedlings of Heritiera fomes and Excoecaria spp. (Rawson \& Munns, 1984). Stomata of the flowers are blocked by oil pollution, which is hampering the growth of plants. Because of increased salinity, Heritiera fomes and Nypa fruticans were declining quickly (Gopal\& Chauhan, 2006). The essential purpose for top-dying of the species is accepted to be the expanding dimension of salinity (Zaman et al., 2014).

The people living close to the Sundarban rely upon the rivers for water. The slick oil influences the water of these streams, and their saltiness expands; this poses dangers to the inhabitants. People, animal and vegetation, are experiencing some sicknesses, and subsequently, the number of species in Sundarban is going down day by day.

\section{CONCLUSION}

Sundarban plays an imperative role for the general population of the southwestern shoreline of Bangladesh. But it is being degraded day by day. It protects from coastal disaster, assist and provide public and private goods. The study concluded that the main causes of degradation were: increased shrimp farming, oil spillage and pollution increased over-dependency of the population and illegal forest cutting, forest fire, management failure, plant diseases, upstream withdrawal of river water and salinity intrusion.

In Bangladesh, the present Forest Act does not arrange to allow participatory preservation of the forest. The government of Bangladesh has attempted to introduce some initiatives to conserve this important ecosystem. Still, the sustainability of its resources most likely never be executed because of the absence of sound procedures. A sustainable administration layout may be developed involving all beneficiaries and stakeholders and ought to be successfully applied to conserve the world's biggest mangrove ecosystem for current and future generations.

\section{ACKNOWLEDGEMENT}

The authors acknowledge the anonymous reviewers for their valuable suggestions and comments that improved the quality of this research article. We are also in-depth with our gratitude to the Department of Environmental Science and Disaster Management, Noakhali Science and Technology University, Bangladesh, to supply the necessary supports to accomplish the study. 


\section{REFERENCES}

Agrawala, S., Ota, T., Ahmed, A.U., Smith, J., \& Van Aalst, M. (2003). Development and climate change in Bangladesh: focus on coastal flooding and the Sundarbans. OECD Paris.

Akhtaruzzaman, A.F.M. (2004). Mangrove forestry research in Bangladesh. Mangrove Management and Conservation: Present and Future, 249-256.

Ali, M., Kabir, M.A., \& Hoque, A.T.M. (2006). People, policy, and perpetuity: Sustainability indicators of Bangladesh forestry. Electronic Green Journal, 1(24). 1-23

Ali, S. S. (1994). Sundarbans: Its resources and ecosystem. Proceedings of the National Seminar on Integrated Management of Ganges Flood Plains and Sundarbans Ecosystem, 16-18.

Anon. (2001). Report on socio-economic baseline study on the impact zone of the Sundarbans. Urban and rural planning discipline Khulna University, Khulna, Bangladesh.

Aziz,A., \& Paul, A.R. (2015). Bangladesh Sundarbans: Present status of the environment and biota. Diversity, 7(3), 242-269.

Banglapedia. (2010). National encyclopedia of Bangladesh. Asiatic Society of Bangladesh, Dhaka, Bangladesh.

Basak, J.K., Titumir, R.A.M., \& Dey, N.C. (2013). Climate change in Bangladesh: A historical analysis of temperature and rainfall data. Journal of Environment, 2(2), 41-46.

Bhowmik, A. K., \& Cabral, P. (2013). Cyclone sidr impacts on the Sundarbans floristic diversity. Earth Science Research, 2(2), 62.

Borrell, A., Tornero, V., Bhattacharjee, D., \& Aguilar, A. (2016). Trace element accumulation and trophic relationships in aquatic organisms of the Sundarbans mangrove ecosystem (Bangladesh). Science of the Total Environment, 545, 414-423.

CEGIS. (2006). Coastal land use zoning in the South-west: Impact of sea level rise on landuse suitability and adaptation options.

Chaffey, D.R. (1985). A forest inventory of the Sundarbans. Bangladesh. Main Report, Project, 41.

Chakravortty, S., \& Ghosh, D. (2018). Automatic identification of saline blanks and pattern of related mangrove species on hyperspectral imagery. The $4^{\text {th }}$ International Conference on Recent Advances in Information Technology (RAIT), 1-6.
Deb, M., \& Ferreira, C.M. (2017). Potential impacts of the Sunderban mangrove degradation on future coastal flooding in Bangladesh. Journal of Hydro-Environment Research, 17, 30-46.

Didar-Ul Islam, S.M., Bhuiyan, M.A.H., \& Ramanathan, A.L. (2015). Climate change impacts and vulnerability assessment in coastal region of Bangladesh: A case study on Shyamnagar Upazila of Satkhira District. Journal of Climate Change, 1(1, 2), 37-45.

Dutta, D., Das, P.K., Paul, S., Sharma, J.R., \& Dadhwal, V.K. (2015). Assessment of ecological disturbance in the mangrove forest of Sundarbans caused by cyclones using MODIS time-series data (2001-2011). Natural Hazards, 79(2), 775-790.

FAO. (2000). State of world's forests 2000. Food and Agriculture Organization, Rome.

Gopal, B., \& Chauhan, M. (2006). Biodiversity and its conservation in the Sundarban mangrove ecosystem. Aquatic Sciences, 68(3), 338-354.

Habib, A. (2011). Climate change: Bangladesh perspective. Retrieve from: //www.dccc.iisc. ernet.in/22July2011-Policy/ArjumandHabib. doc on the $1^{\text {st }}$ December 2020.

Hossain, S.R., Ahmed, I., Azad, F.S., \& Hasan, A.S.M.M. (2020). Empirical investigation of energy management practices in cement industries of Bangladesh. Energy, 212, 118741.

Iftekhar, M.S., \& Islam, M.R. (2004). Degeneration of Bangladesh's Sundarbans mangroves: A management issue. International Forestry Review, 6(2), 123-135.

IPAC. (2012). Integrated protected area comanagement. State of Bangladesh's forest protected areas.

Islam, M.S., \& Wahab, M.A. (2005). A review on the present status and management of mangrove wetland habitat resources in Bangladesh with emphasis on mangrove fisheries and aquaculture. Aquatic Biodiversity II, 165-190.

Islam, N. (2005). Environmental issues in Bangladesh: An overview. Pakistan Journal of Social Science, 3(4), 671-679.

Islam, S.M.D.U., \& Bhuiyan, M.A.H. (2018). Sundarbans mangrove forest of Bangladesh: Causes of degradation and sustainable management options. Environmental Sustainability, 1(2), 113-131.

Islam, S. M. D. (2013). Evaluation of environmental and socio-economic impact due to cyclone 
Aila, present condition and adaptation practices in Shyamnagar, Satkhira of Bangladesh. (Undergraduate Thesis). Department of Environmental Sciences, Jahangirnagar University, Dhaka.

Islam, S.N., \& Gnauck, A. (2011). Water salinity investigation in the Sundarbans rivers in Bangladesh. International Journal of Water, 6(12), 74-91.

IUCN. (2000). Red list of threatened animals of Bangladesh.

IUCN. (2001). The Bangladesh Sundarbans: A photoreal sojourn.

IUCN. (2003). Conservation monitoring of Sundarban biodiversity. In Biodiversity health status workshop proceedings.

Karim, S. (2012). REDD+ and mangroves: A study on Sundarbans. APCEL/NCSS Workshop on REDD + and legal regimes of mangroves, peatlands and other wetlands: ASEAN and the World.

Khan, Mohammad Ali Reza, Dipu, S., \& Ahmed, F. (2013). Sundarban: Rediscovering Sundarban: the mangrove beauty of Bangladesh. Nymphea Publication.

Khan, Mohammed Ali Reza. (1986). Wildlife in Bangladesh mangrove ecosystem. Journal of the Bombay Natural History Society. Bombay, 83(1), 32-48.

Miah, G., Bari, N., \& Rahman, A. (2010). Resource degradation and livelihood in the coastal region of Bangladesh. Frontiers of Earth Science in Cbina, 4(4), 427-437.

Mirza, M. Q., Warrick, R. A., Ericksen, N. J., \& Kenny, G. J. (1998). Trends and persistence in precipitation in the Ganges, Brahmaputra and Meghna river basins. Hydrological Sciences Journal, 43(6), 845-858.

MoEF. (2005). National biodiversity strategy and action plan for Bangladesh.

MoEF. (2010). Integrated resources management plans for the Sundarbans.

Naskar, K., \& Mandal, R. (1999). Ecology and biodiversity of Indian mangroves (Vol. 1). Daya Books.

Paul, A.K., Ray, R., Kamila, A., \& Jana, S. (2017). Mangrove degradation in the Sundarbans. In Coastal wetlands: alteration and remediation (pp. 357-392). Springer.

Paul, B.G., \& Vogl, C. R. (2011). Impacts of shrimp farming in Bangladesh: Challenges and alternatives. Ocean \& Coastal Management,
54(3), 201-211.

Peng, L., \& Qin, F. (2000). Environmental ecology and economic utilization of mangroves in China. Beijing: China Higher Education Press.

Rahman, L.M. (2000). The Sundarbans: A unique wilderness of the world. USDA Forest Service Proceedings RMRS-P-15-(2), 143-148.

Rahman, M.R. (2015). Causes of biodiversity depletion in Bangladesh and their consequences on ecosystem services. American Journal of Environmental Protection, 4(5), 214236.

Rahman, M.T.U., Rasheduzzaman, M., Habib, M. A., Ahmed, A., Tareq, S. M., \& Muniruzzaman, S. M. (2017). Assessment of fresh water security in coastal Bangladesh: An insight from salinity, community perception and adaptation. Ocean \& Coastal Management, 137, 68-81.

Rahman, Mohammed M., Rahman, M.M., \& Islam, K.S. (2010). The causes of deterioration of Sundarban mangrove forest ecosystem of Bangladesh: Conservation and sustainable management issues. Aquaculture, Aquarium, Conservation \& Legislation, 3(2), 77-90.

Rahman, Mahabubur M., Chongling, Y., Islam, K. S., \& Haoliang, L. (2009). A brief review on pollution and ecotoxicologic effects on Sundarbans mangrove ecosystem in Bangladesh. International Journal of Environmental Engineering, 1(4), 369-383.

Rahman, S. (2012). Impacts of climate change on ecological composition \& biodiversity of Sundarbans, Bangladesh. A Conference in the Philippines. Retrieved from: http://www. Ched. Gov. Ph/Chedwww/Index. Php/ Eng/Content/Download/1792/9300/File/ Impacts_CC_Sundarban_Shahriar_Rahman. Pdf. Accessed, 15. on the $1^{\text {st }}$ December 2020.

Rahman, S.H., Islam, S.M.D., \& Rume, T. (2016). Seawater intrusion in coastal region of Bangladesh: Causes, impacts and adaptation. Journal of SUB (Special Issue on Environment), 6(2), 44-63.

Rawson, H.M., \& Munns, R. (1984). Leaf expansion in sunflower as influenced by salinity and short-term changes in carbon fixation. Plant, Cell \& Environment, 7(3), 207-213.

Ruitenbeek, H. J. (1998). Research note: Economic model summary and applications for sustainable forest management. In H.J. 
Ruitenbeek (Eds.). Resource Consulting Limited, Gabriola, BC, Canada.

Saadi, M.L.K. (2010). Hurricane sidr claims beautiful mangroves. Retrieved from http://www. Islamonline.Net. on the $1^{\text {st }}$ December 2020.

Shamsuzzoha, M., \& Biswas, A. (2010). Sustainable biodiversity management of the Sundarban: Disaster management perspetive.

Siddiqi N. A. (1998). Enrichment planting in the Sundarbans: A review. Bangladesh Journal of Forest Science, 27, 103-113.

The Daily Star. (2014). Oil spills into river as tanker sinks at Sundarbans. The Daily Star. Retrieved from https://www.thedailystar. net/oil-spills-into-river-as-tanker-sinks-atsundarbans-54377 on the $1^{\text {st }}$ December 2020.

Timberg, T.A. (1991). Sundarbans-goods, markets and value. The commons in South Asia: societal pressure and environmental integrity in the Sundarbans. Retrieved from http:// Www. Smartoffice. Com/Tiger/Proceedings. Html. on the $1^{\text {st }}$ December 2020.

Uddin, M.S., van Steveninck, E. de R., Stuip, M., \& Shah, M.A.R. (2013). Economic valuation of provisioning and cultural services of a protected mangrove ecosystem: A case study on Sundarbans Reserve Forest, Bangladesh. Ecosystem Services, 5, 88-93.
UNESCO. (2007). The Sundarbans UNESCO World Heritage Centre.

World Bank. (2000). Bangladesh - Climate change and sustainable development. Retrieved from http://documents.worldbank.org/curated/ en/906951468743377163/BangladeshClimate-change-and-sustainable-development on the $1^{\text {st }}$ December 2020.

World Bank. (2010). Economics of adaptation to climate change: Synthesis Report. Retrieved from https://openknowledge.worldbank. org/handle/10986/12750 on the $1^{\text {st }}$ December 2020.

WWF. (2007). Rising sea levels threaten to wash away entire nations. Retrieved from http:// www.panda.org on the $1^{\text {st }}$ December 2020.

Zaman, S., Bhattacharyya, S.B., Pramanick, P., Raha, A.K., Chakraborty, S., \& Mitra, A. (2014). Rising water salinity: A threat to mangroves of Indian Sundarbans. In Water insecurity: $A$ social dilemma. Emerald Group Publishing Limited. 